\title{
The Relation between Teachers' Self-beliefs of L2 Learning and In-class Practices
}

\author{
Frezia sheikhol-Eslami \\ Department of English Language, Faculty of Letters \& Humanities, Najaf Abad Branch, Islamic Azad University, \\ Esfahan, Iran \\ Email: Eslami.2225@yahoo.com \\ Hamid Allami \\ Department of English Language, Faculty of Letters \& Humanities, Yazd University, Iran \\ Email: hamid_allami@yahoo.com
}

\begin{abstract}
This study examined the relationship between Teachers' self-belief of $\mathbf{L 2}$ learning and in-class practices and decisions. Thirty $\mathrm{L} 2$ teachers and $50 \mathrm{~L} 2$ learners participated in this study. To assess the learners' general proficiency level, a standard Proficiency test (Oxford Placement Test, 2010) was administered. The participants were given a questionnaire including 22 questions specialized in teacher institutional design. Thirty teachers were observed by the researcher along with two colleagues as raters to achieve interrater reliability. Each teacher was observed two to five sessions continuously, their teaching was recorded by MP3 player to review again if needed. Some questions were specially designed to determine the teachers' justification about what they did, behaved, and decided during language teaching according to teachers' responses to the TBQ (Teacher Belief Questionnaire) and researchers' observation checklist. The results of the study showed that teachers' self-belief of $\mathrm{L} 2$ learning exert no particular sort of effect on $\mathrm{L} 2$ teachers' decision-making process and in-class instructional practices.
\end{abstract}

Index Terms - teacher cognition, decision-making skill, teachers' self-belief

\section{INTRODUCTION}

As Freeman (1991) pointed out, teaching is a decision-making process in terms of knowledge, skill, attitude, and awareness. Teachers are, then, decision-makers who process information, acting upon those decisions within complex teaching environments (Johnson, 1992).

Nunan and Lamb (1996) pointed out that the planning for L2 teaching includes three elements: 1) knowledge of language learners and their needs, 2) a set of goals and objectives, and 3) a personal view of the nature of the L2 and L2 learning. They maintain that there are different decision-making points in L2 teaching. Their comprehensive list entails objective, content including linguistic content (grammar) and other content (tasks for the day), evaluation, classroom talk, instruction methods, error correction and feedback, questions, use of first language (L1), assignments, dealing with behavior problems, L2 teachers' and learners' roles, small group and pair work, large classes, one-to-one instruction, self-directed learning, mixed-level groups, motivation, anxiety, and attitude. Although difficult to closely follow the requirements of this list, it appears necessary for L2 teachers to learn all the strategies to be employed in planning programs and decision-making. Indeed L2 teachers tend to give the greatest prominence to the needs, interests and abilities of their learners, followed by the subject matter, goals, and teaching methods.

It is impossible, however, to make the same decisions in similar situations. L2 teachers sometimes decide to make a decision on the actual time and place of teaching according to the present circumstances (Woods, 1996). This demonstrates the unpredictable nature of this process; one action may lead to another action within L2 teachers' understanding and interpreting, or one action is part of larger events that include unforeseen consequences (Woods, 1996). That is why in L2 learning, L2 teaching behaviors are considered as causes and learners' learning is considered as effect.

A number of researchers focused on discussing L2 teachers' actions in the classroom; the kind of instructional practices during their teaching, and trying to find out the cognition underlying these practices (e.g., Clandinin \& Connelly, 1987; Clark \& Peterson, 1986; Fang, 1996; Kagan, 1990; Pajares, 1992).

Like other components of L2 teaching, the L2 teacher conception of L2 learning can be debatable in the sense to find out whether they employ the same method through which they have learned or acquired an L2. Woods (2000) highlighted that any hand-on practice which makes L2 teachers bring up ideas generated from reflection, self-discovery, self-renewal, and self-development can be efficient. Moreover, it can considerably advance those strategies of teaching through in L2 teachers implement decisions and plans in the classroom. Besides, Tan and Lan (2010) stated that L2 teachers adopted their classroom instructional practices based on what was necessary to be learned and comprehended by L2 learners to help their learners understand the lessons perfectly. 
Nevertheless, the problem arises when teachers, learners, and institutes' principals are not completely aware of what to do and how to focus correctly on learners' learning in the classroom. Iranian language teachers in conversation classes are unaware of what really involves in learning a language, only pay attention to one or some specific aspects of language learning, resulting in the negligence of teachers' decision making process.

What teachers know, believe, and think is the unobservable cognitive dimension of teaching. In the last 25 years the impacts of teacher cognition on teachers' professional lives have been recognized (Calderhead 1996; Carter 1990; Clark \& Peterson 1986; Fenstermacher 1994; Richardson 1996; Verloop, Van Driel, \& Meijer 2001). According to Borg (1997), teachers have cognition about all aspects of their works. Teacher cognitions and practices are on a part informing; contextual factors playing an important role in determining the extent to which teachers are able to implement instruction congruent with their cognitions (e.g., Beach 1994; Tabachnick \& Zeichner 1986). Teacher cognition plays a pivotal role in teachers' lives (Freeman, 1966, 2002). In the 1990s a bulk of research on teacher cognition started to appear. Here is the review of the chronology of research on L2 teacher cognition:

There have been 22 studies which have shown the relationship between teacher cognition and grammar teaching. Besides, there are a few other studies which highlighted the teacher cognition and literacy instruction (Borg, 1998; Johnson 1996).

As Fenstermacher (1994) and Orton (1996) assert, teacher cognition is completely a process which has a personal nature where experience has a pivotal role in development of this personal nature of cognition. Both cognition and instructional practices are mutually informing.

According to Almarza (1996), there is a relationship between teachers' knowledge and education with classroom practice. Any change in the origin and content of teacher cognition has an impact on classroom practices.

As Borg (1996) stated, cognition as an inclusive term includes the complexity of teachers' mental lives, and of the relationship between cognition and practice. Cognition is divided into three major parts:

a) Cognition and prior language learning experience

b) Cognition and teacher education

c) Cognition and classroom practice

Borg (1996) highly emphasized the value of observation in the study of L2 teacher cognition. What and how teachers think and what actually takes place in the classroom are correlated with value and ability of observation (Borg, 1996). In teacher cognition research, interview and/or self-report data are taken into account. In order to emphasize the crucial importance of observation, it is necessary to understand various dimensions of observation which are discussed here, Borg (2006) suggests a careful requirement of attention, including the observer's role, the authenticity of the setting, disclosure to teachers, the recording of observations, the coding and analyzing of observations, and the scope of observations.

Primarily, to ensure better quality inside the classroom, the activities are largely defined as observable teacher and learner behavior. An integration of personal attributes (e.g., care, humor, patience) and professional preparation is called the conceptualization of the teaching process.

Roberts (1998) puts forward his suggestion in which teachers' behavior in class depends on their perceptions of the incidents which make up classroom life and as he suggests teaching is a social activity. He adds that perception of teachers of the classroom is not a phenomenon which is able to develop in isolation. Hyde (1995), Kramsch and Sullivan (1996), Roberts (1998), Somekh (1993), and views the classroom setting accommodation not to be like testtube samples of school and local culture.

Needless to say that teachers' thinking and teachers' behavior in the class is influenced by school climate and occupational culture. Teachers usually do not show prudence or have too little prudence in managing learning in the class and "giving the lesson" is an issue which they feel responsible for that. Obviously, they were not used for reflecting on their own practice, to put it in this way, teachers by no means observed each other, and had rarely been observed.

Abell, Dillon, Hopkins, McInerney, \& O’Brien (1995), Tellez (1992) and Wildman, Magliaro, Niles, \& Niles (1992) offered the extreme instance of how an unwilling or not a-well-qualified teacher may have had to become a mentor teacher and due to this mentor/ mentee collaboration, the mentoring process has been negatively affected.

All immediate arrangements about possible threats to the order of the classroom were managed by teachers called 'classroom management' in which problems have been foreseen by teachers before they actually accrued.

To go through teachers' behavior, 'discipline' is another subject to be taken into account which refers to an occasion interrupting the course of the lesson in class, where a teacher has to make a change to solve a discipline problem. In the same vein, all cooperating teachers were supposed to have reacted to a problematic situation in class.

Learners' beliefs have the potential to influence both their experiences and actions based on the existing research suggested by Puchta (1999) and Stevick (1980).

Teacher beliefs clarify the ideas that influence the way they conceptualize teaching. As Pajares (1992) argues, what it takes to be an effective teacher and how learners ought to behave are relevant subjects in this domain.

In order to understand teachers' belief, one needs to assess the process of how teachers conceptualize their work. What are the sources of teachers' core beliefs? 
For novice teachers, classroom experience and day to day interaction with colleagues has the potential to influence the relationship among beliefs and principals. To consolidate with the principal can promote their beliefs overtime. The more experienced the teachers are, the more reliant on the core principal beliefs and less conscious about doing so they are. The most resilient teachers' beliefs are formed on the basis of teachers' own schooling as young learners. Teacher's conceptualization about learning, teaching and language is more correlated with their belief system concerning such issues as human nature, society, education and culture.

Peacock (2001) and Richards, Tung, and Ng (1992) did larger scale surveys of teachers' beliefs. According to Hofer and Pintrich (1997) and Schommer (1993), to be engaged with teacher beliefs of knowing and learning in the field of epistemological beliefs lead us to provide insights into the improvement of teaching and learning among novice teachers. Epistemological beliefs are scopes for change; change in experience which reflects both education and homelife.

In a same vein, teachers are life-long learners able to critically reflect on their actions and teaching; they are knowledge workers in need of being self-regulated, as Brownlee (2004) argued. In contrast, Schommer (1994) asserts something related to multidimensional and flexible nature of (some) teachers' beliefs.

As mentioned above, teachers' beliefs are the crucial issue needed to be considered and addressed in teacher education courses (Anders, Lloyd, Tidwell, \& Richardson, 1991; Fang, 1996). This study is, thus, an attempt to explore different problems for those who are spending time, money and energy in L2 teaching and learning process.

\section{METHODOLOGY}

\section{A. Participants}

The main participants in this study were 30 L2 teachers teaching in Jahad Danshgahi Education Centers (Panjeramazan \& Najaf Abad branch), Najaf Abad Azad University, Sadr Language institute, Novin Language Institute, Azad University of Brujerd, Paradise Institute, Shahin-Shahr Payam e Noor,and Isfahan University. They were randomly selected from among 50 teachers in the above centers.

Also, another group of participants, 100 learners, were examined. To assess the learners' general proficiency level, a standard Proficiency test (Oxford Placement Test, 2010) was administered; including 100 grammar items. It took about an hour for the participants to complete it. Fifty male and 50 female learners were selected studying Top Notch series in conversation classes. Learners participated in this study were selected from all the above mentioned universities and levels.

\section{B. Materials}

In this study, four types of materials were employed for data collection: Teacher Beliefs Questionnaire (TBQ), Observation Checklist, Interview, and daily lesson plans.

\section{Procedure}

Firstly, the researcher surveyed and observed some other teachers in different English centers mentioned before by TBQ. After surveying the teachers' and learners' notes and adopting some items from Bredekamp and Copple (1997), Dian and Burts (1990), Kim (2005), Tschannen-Moran and Hoy (1998) a questionnaire was designed including 22 questions specialized in teacher institutional design.

Some teachers complained about some questions which were ambiguous to them, and some of them recommended that the number of items in each topic be matched with the research questions. Therefore, the researcher decided to revise the questioner once more. The revised questionnaire included 19 items in 4 sections. Also, 4 items were revised.

Secondly, thirty teachers were observed by the researcher along with two colleagues as raters to achieve interrater reliability. Each teacher was observed two to five sessions continuously, their teaching was recorded by MP3 player to review again if needed. The researcher and raters sat in the corner of the class not to distract learners' and teachers' attention. In order to investigate the main purpose of the study, the researcher kept an eye on L2 teacher carefully. The Observation Checklist (adapted from Dunkin, 1996 and Cumming, 1989) included 20 questions, four sections in which 5 related items were designed; teachers' education, teachers' schooling experience, teacher's self-beliefs and teachers' adaptability. It enjoyed three choices from 1 (yes), 2(no), and 3(other); as the latter was related to any teacher reaction which was not completely positive or completely negative.

Then, some questions were specially designed to determine the teachers' justification about what they did, behaved, and decided during language teaching according to teachers' responses to the TBQ and researchers' observation checklist.

The questions were used to tap teachers' cognition both in their beliefs and decision-making behaviors. Every interview was done just after the class was over. Every teacher in the staff room was asked to respond a few questions designed by the researcher which took 40 minutes. In order to guarantee maximum inter-rater reliability, each interview was recorded by MP3 player to be listened by two raters for its cognitive density and the average density of each interview was finally calculated. For some of the teachers who were not found in the staff room after the class, the researcher corresponded with them via e-mail or talked to them on the telephone. 
Finally, in order to have a precise density of teachers' in-class decision-making a daily lesson plan was written by teachers a day before the session which was observed by the researcher. They were supposed to write exactly whatever they were going to do in the classroom. Some teachers filled it out some hours before the class was going to start. These daily lesson plans were used to see whether they behaved as they believed or they might do improvisational teaching. Daily lesson plan was weighted in six sections, lesson content, duration, objective(s), procedure, assessment, and assignment. A sample was designed by the researcher to help teachers to fill it out. L2 teachers were asked to write the two most important parts of their teaching plan.

The present study was conducted in Jahad Education Center and in conversation classes of English Department of Najaf Abad Azad University. As it was illustrated in the participants' section, 50 learners were selected from a total of 100 participants on the basis of their scores OPT (1992) and 30 English teachers of both sexes. Out of 100 learners, 50 learners whose categorized into seven groups of beginner, false beginner, basic, elementary, lower intermediate, upper intermediate, and very advanced, were selected. Of course they were not aware of the fact that they were selected to take part in this research.

In order to observe the teachers' behaviors, decision-making directly, 2-5 sessions of observation of each teacher were attended to by the researcher during one semester. To access inter-observer reliability, another observer also filled out the checklists. The inter-observer reliability was .552. For being minimally intrusive, the observers sat in the back of the class, in order not to make the participants distracted by their note taking.

Since observations could not be considered sufficient for the researcher to have access to all participants' cognition, beliefs and decision-making, in addition to class observations, two sets of questionnaires and a daily lesson plan were administered to the participants.

Prior to launching the main study, the homogeneity of the group was confirmed by a pilot study. A group of Ph.D. English instructors and some students who were teachers too comprised part of the population.

In order to ascertain the validity of the questionnaires, two sets of questionnaires were given to 20 experienced English Professors of Islamic Azad University, Najafabad Branch, and Esfahan University. The teachers analyzed the content and found one to one correspondence between the content and purpose of the questions. So, the content validity was confirmed. Their comments and suggestions were also gathered.

To ascertain the reliability of the questionnaires, two sets of the learners' questionnaires were piloted with 25 Top notch learners with the same characteristics as those of the participants in Jahad Daneshgahi Education Center. After carrying out the pilot test, necessary revisions were made. L2 teachers' questionnaire (TBQ) was also validated by 20 English university professors, who had experience in teaching conversation in different centers.

After collecting data, the reliability indexes for two sets of the questionnaires were computed. The Cronbach Alpha was used to estimate their reliability indexes and it was acceptable for all questionnaires. The questionnaires reliability were .673 and .64 respectively.

Some learners were provided with the opportunity to complete the questionnaire at home and bring it back the next session. Before administrating the questionnaire, the students were informed of how to fill in; they were asked to write their code number, not their names, so that their identities would remain confidential.

Some teachers filled out the daily lesson plan one day before the session which was supposed to be observed. Others completed the daily lesson plan just one hour before the class was going start. They were asked to write exactly the instruction practice that they were going to perform during teaching.

After collecting the learners' opinions and attitudes in order to determine L2 teachers' decision-making in their classes, the instructors' questionnaire was distributed among 30 English teachers, 24 English educated teachers and 6 Non-English educated teachers, who were selected according to their experience in L2 teaching and their eagerness to take part in this study. Moreover, they were asked to complete the English questionnaire in the staff room.

\section{DATA ANALYSIS}

The Teacher Belief Questionnaire (TBQ) composed of 19 questions in 4 sections with the responses which were developed by the English instructors in a likert scale from strongly disagree to strongly agree. The results provided an overall account of the teachers' belief in the course of classroom management and decision-making process. 
TABLE 1

DESCRIPTIVE STATISTICS FOR THE ENGLISH QUESTIONNAIRE

\begin{tabular}{|llllll|}
\hline & $\begin{array}{l}\text { Strongly } \\
\text { disagree }\end{array}$ & $\begin{array}{l}\text { Moderately } \\
\text { disagree }\end{array}$ & No idea & $\begin{array}{l}\text { Moderately } \\
\text { agree }\end{array}$ & $\begin{array}{l}\text { Strongly } \\
\text { agree }\end{array}$ \\
\hline Q1 & $16.7 \%$ & $13.3 \%$ & $.0 \%$ & $16.7 \%$ & $53.3 \%$ \\
Q2 & $6.7 \%$ & $20.0 \%$ & $13.3 \%$ & $40.0 \%$ & $20.0 \%$ \\
Q3 & $3.3 \%$ & $13.3 \%$ & $10.0 \%$ & $36.7 \%$ & $36.7 \%$ \\
Q4 & $.0 \%$ & $13.3 \%$ & $3.3 \%$ & $36.7 \%$ & $46.7 \%$ \\
Q5 & $10.0 \%$ & $26.7 \%$ & $13.3 \%$ & $33.3 \%$ & $16.7 \%$ \\
Q6 & $23.3 \%$ & $23.3 \%$ & $.0 \%$ & $26.7 \%$ & $26.7 \%$ \\
Q7 & $6.7 \%$ & $23.3 \%$ & $10.0 \%$ & $26.7 \%$ & $33.3 \%$ \\
Q8 & $23.3 \%$ & $13.3 \%$ & $23.3 \%$ & $26.7 \%$ & $13.3 \%$ \\
Q9 & $3.3 \%$ & $43.3 \%$ & $10.0 \%$ & $30.0 \%$ & $13.3 \%$ \\
\hline Q10 & $16.7 \%$ & $33.3 \%$ & $16.7 \%$ & $23.3 \%$ & $10.0 \%$ \\
Q11 & $36.7 \%$ & $20.0 \%$ & $10.0 \%$ & $26.7 \%$ & $6.7 \%$ \\
\hline Q12 & $10.0 \%$ & $16.7 \%$ & $13.3 \%$ & $36.7 \%$ & $23.3 \%$ \\
Q13 & $10.0 \%$ & $26.7 \%$ & $13.3 \%$ & $46.7 \%$ & $3.3 \%$ \\
Q14 & $6.7 \%$ & $16.7 \%$ & $6.7 \%$ & $56.7 \%$ & $13.3 \%$ \\
\hline Q15 & $6.7 \%$ & $10.0 \%$ & $16.7 \%$ & $56.7 \%$ & $10.0 \%$ \\
\hline Q16 & $23.3 \%$ & $23.3 \%$ & $16.7 \%$ & $33.3 \%$ & $3.3 \%$ \\
Q17 & $6.7 \%$ & $33.3 \%$ & $3.3 \%$ & $56.7 \%$ & $.0 \%$ \\
\hline Q18 & $16.7 \%$ & $30.0 \%$ & $10.0 \%$ & $26.7 \%$ & $16.7 \%$ \\
\hline Q19 & $\mathbf{1 6 . 7 \%}$ & $\mathbf{3 0 . 0 \%}$ & $\mathbf{3 . 3 \%}$ & $\mathbf{3 0 . 0 \%}$ & $\mathbf{2 0 . 0 \%}$ \\
\hline
\end{tabular}

Following the above records, there were no frequent uses of 'no idea' response through the collected data. The instructors mostly tended to avoid explaining about a part in which they were not good enough at teaching (Question 1), employ the same method through which they learned English (Question 4) and be less motivated to do hard work due to the learners' poor attitude (Question 7). In two cases as correlating the instructional practice with their self-awareness (Question 3) and using the shortage of time excuse to change their lesson plan (Question 6) an equal number of teachers were moderately and strongly agree as the most frequent responses.

Regarding the next response alternative as moderately agree, the instructors most often selected this category in relation to the statements as having a particular daily lesson plan and hence, their success (Question 2), increasing the efficiency through concentration on the learners' needs and expectations (Question 5), the negative role of personal problems in making the best teaching decision (Question 8), changing the lesson plan in conversation classes due to the learners' boredom (Question 12), the more important role of stimulating conversation with fun than following the lesson plan (Question 13), making more instant changes to the lesson plan when regarding the learners' motivation (Question 14), pretending not to see the discipline problems rather than stopping the lesson to deal with them (Question 15), preferring to change decisions by another colleagues' advice before the class (Question 16) and answering the vocabulary problems during an activity (Question 17). Interestingly, regarding the idea of changing the already planned schedule due to lots of absentees (Question 19) an equal number of instructors checked moderately agree as well as moderately disagree.

Concerning the priority of error correction to error explanation (Question 9), ignoring extra questions to guarantee better decision-making process (Question 10) and less adaptability of a teacher with Non-English specialty in answering the learners' questions (Question 18) the instructors most often were moderately disagreed. Finally, in relation to ignoring the learners' errors (Question 11), most of the instructors strongly disagreed with the statement.

The observation checklist included 20 statements which in each class were checked by the researcher for the instructors as employed (Yes), not employed (No) or other strategy alternatives (other) which is related to any teacher reaction which is not completely positive or completely negative.

TABLE 2

DESCRIPTIVE STATISTICS FOR THE OBSERVATION RESULTS

\begin{tabular}{|llllllll|}
\hline & Yes & No & Other & & Yes & No & Other \\
\hline Q1 & $\mathbf{6 3 . 3 \%}$ & $36.7 \%$ & $0.0 \%$ & Q11 & $\mathbf{6 0 . 0 \%}$ & $23.3 \%$ & $\mathbf{1 6 . 7 \%}$ \\
Q2 & $\mathbf{5 3 . 3 \%}$ & $43.3 \%$ & $3.3 \%$ & Q12 & $16.7 \%$ & $\mathbf{7 6 . 7 \%}$ & $\mathbf{6 . 7 \%}$ \\
Q3 & $\mathbf{5 0 . 0 \%}$ & $36.7 \%$ & $13.3 \%$ & Q13 & $\mathbf{3 3 . 3 \%}$ & $\mathbf{3 3 . 3 \%}$ & $\mathbf{3 3 . 3 \%}$ \\
Q4 & $\mathbf{7 3 . 3 \%}$ & $20.0 \%$ & $6.7 \%$ & $\mathbf{Q 1 4}$ & $\mathbf{6 3 . 3 \%}$ & $16.7 \%$ & $\mathbf{2 0 . 0 \%}$ \\
Q5 & $\mathbf{8 6 . 7 \%}$ & $10.0 \%$ & $3.3 \%$ & $\mathbf{Q 1 5}$ & $\mathbf{8 6 . 7 \%}$ & $13.3 \%$ & $\mathbf{0 . 0 \%}$ \\
Q6 & $\mathbf{8 6 . 7 \%}$ & $3.3 \%$ & $10.0 \%$ & $\mathbf{Q 1 6}$ & $33.3 \%$ & $\mathbf{5 6 . 7 \%}$ & $\mathbf{1 0 . 0 \%}$ \\
Q7 & $\mathbf{7 0 . 0 \%}$ & $10.0 \%$ & $20.0 \%$ & $\mathbf{Q 1 7}$ & $\mathbf{6 3 . 3 \%}$ & $20.0 \%$ & $\mathbf{1 6 . 7 \%}$ \\
Q8 & $\mathbf{6 3 . 3 \%}$ & $23.3 \%$ & $13.3 \%$ & $\mathbf{Q 1 8}$ & $33.3 \%$ & $\mathbf{4 6 . 7 \%}$ & $\mathbf{2 0 . 0} \%$ \\
Q9 & $\mathbf{8 3 . 3 \%}$ & $10.0 \%$ & $6.7 \%$ & $\mathbf{Q 1 9}$ & $46.7 \%$ & $\mathbf{5 0 . 0 \%}$ & $\mathbf{3 . 3 \%}$ \\
\hline Q10 & $\mathbf{3 . 3 \%}$ & $\mathbf{8 3 . 3 \%}$ & $\mathbf{1 3 . 3 \%}$ & $\mathbf{Q 2 0}$ & $\mathbf{4 0 . 0 \%}$ & $\mathbf{5 3 . 3 \%}$ & $\mathbf{6 . 7 \%}$ \\
\hline
\end{tabular}

Based on the above recorded judgments, concerning the observation of the planned alternatives, fortunately most of the instructors attended their time management in the class (Question 1), were structured and taught based on their lesson plans (Question 2), actively involve the learners in the class (Question 3), employed the special teaching method suggested by the institute (Question 4), gave prominence to the learners' needs (Question 5), were confident, 
comfortable and enthusiastic (Question 6), motivated the learners to attend the class (Question 7), instructed clearly and perfectly enough (Question 8), corrected all the errors (Question 9), answered any asked vocabulary item during an activity (Question 11), had adaptability to answering different questions (Question 14), did pair works or small group activities (Question 15) and had a content specific knowledge of the teaching topic (Question 17). Interestingly, concerning the issue of having fun time in the classroom (Question 13), no fixed pattern was observed in the classes in a way that some teachers kept it, some did not keep and others provided a different pattern which is related to any teacher reaction which is not completely positive or completely negative.

In the rest of cases most of the teachers did not attend to the checked statements in their classrooms. These issues were related to meeting the class with some absentees and changing the lesson plan (Question 10), stopping teaching and dealing with the learners' misbehaviors (Question 12), avoiding more explanation of a part they were not good at teaching (Question 16), having some tired learners who did not actively participate (Question 18), emphasizing on drilling and repetition (Question 19) and finally, developing the learners' creativity and critical thinking (Question 20).

To ensure the lack of any subjectivity in interpreting the responses, the observed records were coded by another rater as well. The rater was assigned to code the responses in 20 percent of the total cases. The latter results were then analyzed in relation to the researcher's decisions in the course of data analysis. The results of this inter-rater reliability account yielded a high consistency among the two raters' codes with the $r$ value of .55 and a high level of significance $(\mathrm{p}<0.05)$ as well.

TABLE 3.

INTER-RATER RELIABILITY OF THE QUESTIONNAIRE

\begin{tabular}{|l|l|l|}
\hline \multicolumn{2}{|c|}{ INTER-RATER RELIABILITY OF THE QUESTIONNAIRE } \\
\hline \multirow{3}{*}{ Rater 1 } & Pearson Correlation & Rater 2 \\
\cline { 2 - 3 } & Sig. (2-tailed) & $.552^{* *}$ \\
\cline { 2 - 3 } & $\mathrm{N}$ & .000 \\
\hline
\end{tabular}

In the course of classroom decision making, the instructors' own ideas regarding the issue of language learning may affect what they implement in their classes. Hence, concerning this issue, the relation between the teachers' self-beliefs and their in-class instructional practices was examined through a correlation test which did not suggest a significant relation $(\mathrm{p}>0.05)$.

TABLE 4.

THE CORRELATION BETWEEN TEACHERS' SELF-BELIEFS AND IN-CLASS PRACTICES

\begin{tabular}{|c|c|c|c|}
\hline & & Self-beliefs & In-class decision \\
\hline \multirow[t]{2}{*}{ Self-beliefs } & Pearson Correlation & 1 & .054 \\
\hline & Sig. (2-tailed) & & .406 \\
\hline \multirow[t]{2}{*}{ In-class decision } & Pearson Correlation & .054 & 1 \\
\hline & Sig. (2-tailed) & .406 & \\
\hline
\end{tabular}

Yet, to have a more detailed analysis of the distribution of ideas the following crosstab is suggested to go through.

TABLE 5.

Crosstabulation of TEACHERS' SELF-BELIEFS AND IN-Class PRACTICES

\begin{tabular}{|c|c|c|c|c|c|c|}
\hline & & & \multicolumn{3}{|c|}{ In-class decision } & \multirow[t]{2}{*}{ Total } \\
\hline & & & Yes & No & Other & \\
\hline \multirow{6}{*}{ Self-beliefs } & \multirow{2}{*}{ Agree } & Count & 104 & 25 & 11 & 140 \\
\hline & & \% within Experience & $74.3 \%$ & $17.9 \%$ & $7.9 \%$ & $100.0 \%$ \\
\hline & \multirow[t]{2}{*}{ Disagree } & Count & 51 & 16 & 8 & 75 \\
\hline & & $\%$ within Experience & $68.0 \%$ & $21.3 \%$ & $10.7 \%$ & $100.0 \%$ \\
\hline & \multirow{2}{*}{ No idea } & $\%$ within Experience & $72.0 \%$ & $16.0 \%$ & $12.0 \%$ & $100.0 \%$ \\
\hline & & $\%$ of Total & $7.5 \%$ & $1.7 \%$ & $1.2 \%$ & $10.4 \%$ \\
\hline
\end{tabular}

Accordingly, out of 140 agreement responses, 104 cases agreed to employ the experience in the class. Yet, in terms of the disagreement and no idea cases, the teachers preferred to employ them through their class efforts. Probably, this new employment trend caused the insignificant relation in this regard. The extent of difference in the employed trends was further investigated through a Chi-square test.

TABLE 6.

THE DIFFERENCE BETWEEN TEACHERS' SELF-BELIEFS AND IN-CLASS PRACTICES

\begin{tabular}{|l|l|l|l|l|}
\hline & Value & df & Asymp. Sig. (2-sided) & Exact Sig. (2-sided) \\
\hline Pearson Chi-Square & 1.360 & 4 & .851 & .857 \\
\hline Likelihood Ratio & 1.342 & 4 & .854 & .869 \\
\hline Fisher's Exact Test & 1.643 & & & .808 \\
\hline Linear-by-Linear Association & .693 & 1 & .405 & .418 \\
\hline
\end{tabular}


Based on the results, the difference between the beliefs and in-class practices did not reach significance $(\mathrm{p}>0.05)$. Therefore, in-class practices were not directly affected by the teachers' own beliefs about language learning.

\section{Discussion AND CONCLUSION}

According to the question which is related to teachers' self-belief of L2 learning and decision-making, the finding revealed that there is no significant relationship between teachers' self-belief of L2 learning and decision-making. This result does not support Tan and Lan's (2010) study in which teachers had adapted their classroom linguistic practices based on what they believed to be necessary for content learning and what was most effective in terms of Learner comprehension.

The findings of the study considering Learners' learning outcomes is in direct contrast with Richardson Bruna et al. (2007) study. They concluded that teachers simplify the language and just focus on the key words or terms which are in contrast with their beliefs. Survey comments, classroom observations and learner' comments show that what teachers do in the classroom is directly in contrast with what they have noticed in their daily lesson plan. Another reason might be the lack of teachers' responsibility for learning process during teaching.

The literature in this field shows that teacher beliefs and theories about L2 teaching, learning and their subject matter are important factors in classroom decisions (Sato \& Takahashi, 2004; Tsui, 2003). Teacher cognition is influenced by what teachers reflect on the relationship between what they believe in principal and what is feasible in practice (Borg, 2008). That is why role-play games, group works and stimulation were rarely observed, therefore this contradiction is permanently between what L2 teachers say they do in the class and what they actually do.

Studies across both language classrooms and subject matter classrooms demonstrate that teachers' views about these key areas are determinant in the planning of lessons, and the teaching and learning activities that happen in the classroom (Cole, 2009; Sato \& Kleinsasser, 1999). They influence choices concerning what to teach; how and when to teach it; and how to deal with learners' problems and misunderstandings (Clark \& Peterson, 1986; Johnson, 1992; Shulman, 1986; Sullivan \& Woods, 2008; Woods, 1996). However, L2 teachers' ability to implement their beliefs may also be subject to some other factors such as the school rules and institutional constraints (Cimbricz, 2002; Zanzali, 2003) and it seems that they are required to respect the norms prevalent in their institutions and also teach according to the requirements of a specific curriculum is dictated to them. It seems it is due to limits of their scope for implementing their own teaching instructional practices which are consistent with their own pedagogical stance. Regardless of teachers' personal opinion on this subject, the observation of the classroom teaching show that teachers are not conducting their lesson in English or not even based on what they noticed in their daily lesson paper. It is quite clear from their comments and classroom practices that they believe some other factors like institute's T.T.C (Teacher Training course), time management, and less-proficient learners which learning takes place in bilingual classroom should be supported rather than their own beliefs on teaching. According to the 12 teachers' observation and interviews, those who are usually in weaker classes, rarely teach in English, not in accordance with what they must do to be a good teacher which is in contrast with their beliefs according to TBQ. The result of this study is in accordance with Borg's (2008) study regarding teachers' beliefs and what they actually do in the classroom. He maintained that there is a contradiction between what teachers say they do in the class and what they believe about teaching.

So, as things stand, the following directional statement comes into view:

There is no significant relationship between teachers' self-beliefs of L2 learning and their in-class (instructional) practices.

\section{APPENDIX A SAMPL TEACHER BELIEFS QUESTIONNAIRE (TBQ)}

Instructions: Please read each sentence and rate it by filling in a number between 1 and 5 . The numbers.

\begin{tabular}{|l|l|l|l|l|l|}
\hline Items & $\begin{array}{l}\text { Strongly } \\
\text { Disagree }\end{array}$ & $\begin{array}{l}\text { Moderately } \\
\text { Disagree }\end{array}$ & $\begin{array}{l}\text { No } \\
\text { Idea }\end{array}$ & $\begin{array}{l}\text { Moderately } \\
\text { Agree }\end{array}$ & $\begin{array}{l}\text { Strongly } \\
\text { Agree }\end{array}$ \\
\hline $\begin{array}{l}\text { 1. I have accurate daily lesson plan for teaching, } \\
\text { so I am more successful than other teachers. }\end{array}$ & & & & & \\
\hline $\begin{array}{l}\text { 2. I often employ the same method through } \\
\text { which I learned English. }\end{array}$ & & & & & \\
\hline
\end{tabular}

APPENDIX B SAMPLE CLASSROOM OBSERVATION CHECKLISTS

\begin{tabular}{|l|l|l|l|}
\hline \multirow{2}{*}{ items } & \multicolumn{2}{|l|}{ Tallies } & \multirow{2}{*}{ totals } \\
\cline { 2 - 3 } & Yes & No & \\
\hline $\begin{array}{l}\text { 1. The way in which he/she organizes how to spend } \\
\text { his/her time is appropriate. (Time management) }\end{array}$ & & & \\
\hline $\begin{array}{l}\text { 2. Teacher is highly structured and has provided the } \\
\text { lesson plan.( lesson-plan based teaching) }\end{array}$ & & & \\
\hline
\end{tabular}




\section{APPENDIX C: INTERVIEW QUESTIONS}

Why do think you....?

Why do think having an accurate lesson plan makes you a successful teacher?

\section{REFERENCES}

[1] Abell, S. K., Dillon, D. R., Hopkins, C. J., McInerney, W. D.,\& O’Brien, D. G. (1995). Somebody to count on: mentor/intern relationships in a beginning teacher internshipprogram. Teaching and Teacher Education, 11(2), 173-188.

[2] Adams, P. E., \&Krockover, G. H. (1997).Beginning science teacher cognition and its origin in the preservice science teacher program. Journal of Research in Science Teaching, 34, 633-653.

[3] Anderson, L. M., Blumenfeld, P., Pintrich, P. R., Clark, C. M., Marx, R.W., \& Peterson, P. (1995). Educational psychology for teachers: reforming our courses, rethinking our roles.

[4] Anderson, R., Greene, M., \&Loewen, P. (1988). Relationships among teachers' and students' thinking skills, sense of efficacy, and student achievement. The Alberta Journal of Educational Research, 34(2), 148-165.

[5] Borg, S. (1999).Teachers' theories in grammar teaching. ELTJ 53 (3), 157-167.

[6] Borg, S. (2001). Self-perception and practice in teaching grammar. ELT Journal 55 (1), 21-29.

[7] Borg, S. (2003). Teacher cognition in language teaching: a review of research on what language teachers think, know, believe and do. Language Teaching 39, 81-109.

[8] Borg, S. (2006). Teacher cognition and language education: Research and practice. London: Continuum.

[9] Borg, S., (2010).Teacher Cognition and Language Education. Continuum, London.

[10] Boulton-Lewis, G. M., Smith, D. J. H., McCrindle, A. R., Burnett, P. C., \& Campbell, K. J. (2001). Secondary teachers' beliefs about teaching and learning.

[11] Brownlee, J., Purdie, N., \& Boulton-Lewis, G. (2001). Changing epistemological belief in pre-service teacher education. Teaching in Higher Education, 6(2), 247-345.

[12] Brumfit, C., \& Rossner, R. (1992). The 'decision pyramid' and teacher training for ELT. ELT Journal, 36(4), $226-231$.

[13] Burns, A., Knox, J., (2005). Realisation(s): systemic-functional linguistics and the language classroom. In: Bartels, N. (Ed.), Applied Linguistics and Language Teacher Education. Springer, New York, pp. 235-259.

[14] Cakiroglu, E., \& Cakiroglu, J. (2003). Reflections on teacher education in Turkey. European Journal of Teacher Education, 26(2), 253-264.

[15] Calderhead, J., \& Robson, M. (1991). Images of teaching: student teachers' early conceptions of classroom practice. Teaching and Teacher Education, 7 (1). 1-8.

[16] Calderhead, J. (1996). Teachers: Beliefs and Knowledge. In R. C. D. Berliner (Ed.), Handbook of Educational Psychology (pp.709-725). New York: Macmillan.

[17] Cobb, P., \& Bowers, J. (1999).Cognitive and situated learning perspectives in theory and practice. Educational Researcher, 28(2), 4-15.

[18] Collins, J. B., Selinger, S. J., \& Pratt, D. D. (2003). How do perspectives on teaching vary across disciplinary majors for students enrolled in teacher preparation? Retrieved January 27, 2011 from http://teachingperspectives.com//pdf

[19] Freeman, D. (1991). Teacher training, development, and decision making: a model of teaching and related strategies for language teacher education. TESOL Quarterly, 23(1),27-45.

[20] Freeman, D., (1993). Renaming experience, reconstructing practice. Teaching and Teacher Education 9 (5-6), $485-497$.

[21] Freeman, D., \& Richards, J. C. (Eds.). (1996). Teacher learning in language teaching. Cambridge: Cambridge University Press.

[22] Freeman, D. (2002). The hidden side of the work: teacher knowledge and learning to teach. Language Teaching 35, 1-13.

[23] Grossman, P. L. (1990). The making of a teacher: Teacher knowledge and teacher education. New York: Teachers College Press. Teaching and Teacher Education, 7, 1-8.

[24] Holt-Reynolds, D. (2000). What does the teacher do? Constructivist pedagogies and prospective teachers' beliefs about the role of a teacher. Teaching and Teacher Education, 16, 21-32.

[25] Horwitz, E. K. (1985). Using student beliefs about language learning and teaching in the foreign language methods course. Foreign Language Annals, 18, 333-340.

[26] Horwitz, E. K. (1987). Surveying student beliefs about language learning. In A. L. Wenden, \& J. Rubin (Eds.), Learner strategies in language learning (pp. 119-129). London: Prentice-Hall.

[27] Hsia, S. (Eds. 1998), Perspectives on Language Teacher Education. Hong Kong City Polytechnic, Hong KoJacobs, J. K., \& Morita, E. (2002). Japanese and American Teachers' evaluations of videotaped mathematics lessons. Journal for Research in Mathematics Education, 33(3),154-175.ng, pp. 1-21.

[28] Hyde, M. (1995). The teaching of English in Morocco: the place of culture. English Language Teaching Journal, 48(4), 295305.

[29] Johnson, K. E. (1992). Learning to teach: instructional actions and decisions of pre-service ESL teachers. TESOL Quarterly, 26(3), 507-531.

[30] Johnson, K.E., 1994. The emerging beliefs and instructional practices of preservice ESL teachers. Teaching and Teacher Education 10 (4),439-452.

[31] Kim, D. M. (2005). Implications of research on teacher beliefs. Educational Psychologist, 27(1), 65-90.

[32] Mahlios, M., \& Maxson, M. (1995).Capturing pre-service teachers' beliefs about schooling, life, and childhood. Journal of Teacher Education, 46, 192e199.

[33] Nunan, D., \& Lamb, C. (1996). The self-directed teacher: managing the learning process. New York: Cambridge University Press.

[34] Pajares, M. F. (1992). Teachers' beliefs and educational research: Cleaning up a messy construct. Review of Educational Research, 62, 307-332. 
[35] Parise, L. M., \& Spillane, J. P. (2010). Teacher learning and instructional change: how formal and on-the-job learning opportunities predict change in elementary school teachers' practice. The Elementary School Journal, 110(3), 323e346.

[36] Patrick, H., \& Pintrich, P. R. (2001). Conceptual change in teachers' intuitive conceptions of learning, motivation and instruction: the role of motivation and epistemological beliefs. In B. Torff, \& R. J. Sternberg (Eds.), Understanding and teaching the intuitive mind: Student and teacher learning (pp. 117-143).Mahwah: Lawrence Erlbaum.

[37] Peacock, M. (1999). The links between learner beliefs, teacher beliefs, and EFL proficiency. Perspectives,10(1),125-159.

[38] Richardson, V. (1996). The role of attitudes and beliefs in learning to teach. InJ. Sikula (Ed.), Handbook of research on teaching (pp. 376-391). New York: Macmillan

[39] Somekh, B. (1993). Quality in educational research - the contribution of classroom teachers. In J. Edge, \& K. Richards (Eds.), Teachers develop teachers research-papers on classroom research and teacher development. London: Heinemann.

[40] Woods, D. (1996). Teacher cognition in language teaching: beliefs, decision-making and classroom practice. Cambridge: Cambridge University Press.

[41] Woods, D. (2000). Decision-making in language learning: a lens for examining learner strategies. www.woe.edu.pl/archives. Retrieved December 27, 2011 form http://teachingperspectives.com//pdf

Frezia sheikhol-Eslami is an M.A. TEFL graduate of Islamic Azad University, Najafabad Branch. She is currently teaching English at Isfahan Jahad Daneshgahi Education Center and Oil Company at various levels. And, her areas of interest include applied linguistics, sociolinguistics, and L2 methodology.

Hamid Allami is an assistant professor at Yazd University. His area of research includes Applied Linguistics. He has published many articles in both local and international Scholarly journals. 